CDI

18,1

78

\title{
Self-initiated expatriation and migration in the management literature
}

\section{Present theorizations and future research directions}

\author{
Akram Al Ariss \\ Toulouse Business School, Université de Toulouse, Toulouse, France, and \\ Marian Crowley-Henry \\ Department of Management, National University of Ireland Maynooth, \\ Maynooth, Ireland
}

\begin{abstract}
Purpose - This paper aims to offer a critical review of how self-initiated expatriation (SIE) is theorized compared to migration in the management literature and to indicate venues for future research on SIE

Design/methodology/approach - A systematic review has been conducted using the ISI Web of Knowledge database as well as ABI/INFORM in order to include key journals in the management field. Findings - Despite the importance of present theorizations on SIE, the authors show that the literature presents a narrow focus on the most privileged of self-initiated expatriates and presents some important knowledge gaps. In order to fill these gaps, the authors propose a research map for future research on SIE. This map includes four key dimensions. These are: diversity-informed research on SIE; context specific and multilevel understanding of SIE; reflexive approaches to SIE; triangulated methods to studying SIE
\end{abstract}

Research limitations/implications - By proposing a research map with theoretical and methodological implications, this paper increases our understanding of SIE. It offers a guide for future research on SIEs.

Practical implications - Research on self-initiated expatriation needs to be more inclusive and critical in terms of studying the diverse human resources in our contemporary societies.

Originality/value - The paper indicates how research on self-initiated expatriation can become more developed in terms of its theorizations. Furthermore, it proposes a research map for future studies on SIE that is reflexive, relational, diversity-informed, and methodologically-triangulated.

Keywords Expatriates, Migrant workers, Self-initiated expatriation, Migration, International mobility, Job mobility

Paper type General review

\section{Introduction}

While still a relatively under-researched expatriation category in management studies, theories on self-initiated expatriation (SIE) have been bourgeoning and published in leading specialized (e.g. Career Development International and International Journal of Human Resource Management) and general (e.g. Academy of Management Journal and British Journal of Management) management academic journals. The interest in this topic comes with the recognition by academic scholars, business, and policy-makers

Career Development International Vol. 18 No. 1, 2013

(C) Emerald Group Publishing Limite 1362-0436

DOI $10.1108 / 13620431311305962$ 
that SIEs are valuable international human resources that benefit organizations and economies (Dickmann and Baruch, 2011). In this regard, in 2011 the UN Department of Economic and Social Affairs' Population Division estimates that in 2010 there were 214 million individuals who were undertaking an international mobility. This represents an increase of 58 million since 1990 and about 3.1 percent of the total world population. This same report explains that for the period of 2010-2050, the number of individuals moving from developing to more developed regions is expected to be 96 million. Among these individuals, self-initiated expatriates (SIEs) will continue to represent important international human resources for organizations for various reasons. For example, SIEs might have a good understanding of local and international markets, languages, and cultures. They would cost less than traditional corporate expatriates in terms of travel and living costs, salaries, and taxation among other financial issues. All these reasons make it important for companies to understand the nature and management of SIEs.

Despite the growing interest in SIE (e.g. Al Ariss, 2010; Cerdin and Pargneux, 2010; Crowley-Henry, 2012; Richardson, 2009), it remains unclear how it is theorized in management studies compared to other forms of mobility. Berry (2009) and Berry and Bell (2011) have worked on this topic. This paper fills this important knowledge gap by positioning key present theories and future directions for management research on SIE. By doing so, we respond to an important call in this special issue regarding moving towards a more theoretically-grounded understanding of SIE.

For the purpose of this paper, we define SIE as denoting internationally mobile individuals, who have moved through their own agency (rather than through an organizationally-assigned expatriation) to another country for an indeterminable duration. Inkson et al. (1997) are credited with initiating discussion on the previously un-explored category of "self initiated foreign work experience" (SFE), which Suutari and Brewster (2000) developed further in comparing SFEs with organization assigned expatriates. The nomenclature (SFE) has since converged to the widely accepted "SIE" category of international assignee. Nonetheless, the heterogeneity within the SIE category continues to amass attention (Suutari and Brewster, 2000; Al Ariss and Syed, 2011). This paper focuses on SIE theorizations in order to enable a more critical and multi-perspective development of SIE research and knowledge.

Our paper is divided into three parts. In the first part, we introduce the methodology of our review. In the second part, we address the question: How is self-initiated expatriation theorized in the management literature? We answer this question by revealing key problematic facets of the management theorizations on SIE compared to migration. The third part focuses on explaining where future research needs to go with respect to what has been done on SIE to date. We respond to this question by proposing a research map that helps researchers meet the challenges of studying SIE. Our paper offers a unique contribution to the management literature on SIE by offering much needed clarity regarding what we know and where research needs to go in the future.

\section{Methodology}

To provide a review of the management literature, we conducted a series of searches using the ISI Web of Knowledge database, which includes all journals having an impact factor and listed in the Social Science Citation Index. This is important as it allows understanding how self-initiated expatriation is conceptualized in management journals that are recognized to have an impact in the management field. Using the migration in the

literature 
CDI

18,1

keywords of "self-initiated expatriation", "self-directed travel", "self-initiated foreign experience" and "migration" we searched for peer-reviewed journal articles and reviews. The initial research returned 260 articles in social science fields. We then limited the coverage only to articles in the field of management and to journals whose aim and scope had a managerial approach. We chose English as the articles' language and searched for papers available without limiting the date of publication. This reduced the number of studies to 96 articles. Furthermore, using ABI/INFORM complete database, we undertook an additional search in journals (identified in Appendix under the title "Other") that are recognized as important in our field and that were not found in our initial search. The journals that were included and the frequency of their articles on the topic of self-initiated expatriation are listed in Appendix at the end of the paper. In total, we read 110 articles, excluded those that did not link to the topic of self-initiated expatriation, and identified common thematic issues among the remaining ones.

The theorization of self-initiated expatriation in the management literature The term "SIE" is used in the management literature to refer to individuals undertaking an international career experience on their own initiative. Nevertheless, there is an ambiguity in the literature regarding the connection between SIE and migration. In order to elucidate this ambiguity, we attempt to explain how both terms are employed. We delve into the management literature in order to answer two important questions:

(1) How are SIEs portrayed compared to migrants?

(2) What do we know about SIEs compared to migrants?

In this section, we answer these two questions bringing therefore a much-needed clarity to how SIE is theorized in the literature.

\section{How are SIEs portrayed compared to migrants in the management literature?}

Our literature review shows that research on SIEs focus on the most privileged expatriates. Table I summarizes the key characteristics and profiles of SIEs in contemporary management academic publications. We focus on the contextual aspects such as the nature of the economic system in home/host countries as well as the way ethnicity both impacts upon career choices and outcomes of SIEs. First, the literature focuses on SIEs who come from developed countries including Western European states (Crowley-Henry, 2012), USA (Vance, 2005), Australia (Tharenou, 2010), and New Zealand (Thorn, 2009). With few exceptions (e.g. Agullo and Egawa, 2009; Al Ariss and Syed, 2011), when expatriates come from less-developed countries they are most frequently labeled as "migrants" or "immigrants". No rational theoretical or methodological foundation is given to explain such terminology. Instead, this terminological distinction comes to replicate and support a stereotyped image of migrants who are less advantaged in terms of their originating country and ethnic origins. The literature positions "migrants" in stark contrast to SIEs from developed countries. SIEs therefore emerge as agentially more internationally mobile and, as such, benefit from the privilege of "self-initiating" their international mobility.

Such characteristics are linked to structural and individual patterns. At the structural level, undertaking a SIE is described in the context of agreements between countries (often the most developed economies) that facilitate international mobility. 


\section{Characteristics}

Country of origin

Gender

Education and skills

Job positions

Organizations

Period of international mobility

Destination countries

Description of context
Profiles of self-initiated expatriates

Western Europe and USA (Crowley-Henry, 2012; Vance, 2005),

France (Cerdin and Pargneux, 2010), Finland (Jokinen et al., 2008), United Kingdom (Richardson, 2006), Germany, Australia (Tharenou and Caulfield, 2010), New Zealand (Thorn, 2009), Lebanon (Al Ariss and Syed, 2011), India (Agullo and Egawa, 2009) and other regions from in cross-country studies (Bergh and Plessis, 2012)

Less focus on ethnic minorities (Berry, 2009; Al Ariss, 2010)

Men and women represented in the samples with an interest in understanding gender impact on expatriate experiences (Myers and Pringle, 2005; Tharenou, 2010; Selmer and Lauring, 2011a; Berry and Bell, 2011)

Most of the studies focus on highly educated and qualified individuals (Suutari and Brewster, 2000)

They are described to be endowed with a career capital: knowhow, social capital, and motivations (Cao et al., 2012)

Top managers, executives, middle managers (Biemann and Andresen, 2010)

Multinationals and medium size companies

Varies between short (few months) to longer terms (several years) and permanent (Al Ariss, 2010)

Japan, France, Italy, Saudi Arabia, United Arab Emirates among other countries

Focus on globalization with little attention given to national, regional, and local contexts

Focus on the agency of SIEs and their ability to act (Doherty et al., 2011)

\section{SIE and migration in the literature}

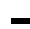

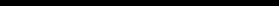

Table I.
Who SIEs are in the management literature?

For example, this includes UK and Australia, Canada and France, mobility and work in the EU for European citizens. Indeed one of most important rights for $\mathrm{EU}$ citizens is their freedom to move and work across the EU member states (Eures, 2012; Eurofound, 2012). This freedom is extended to students and professors through the EU Erasmus program (European Commission Education \& Training, 2012) and to academic researchers via the Marie Curie research mobility program (European Commission Research, 2012). At the individual level, SIEs are often portrayed to freely choose where to go and when to return back to their home countries. For example, in a recent study, Tharenou and Caulfield (2010) explain why and how professionals who self-initiate their expatriation repatriate. The authors conducted a longitudinal study on 546 Australians. Results show that participants were more likely to repatriate when it was easy to do so, rather than because of undesirable outcomes. Similarly, Doherty et al.'s (2011) recent study reconfirms the individual choice aspect (including the choice on the destination and duration of the stay) for SIEs. Richardson and Mallon's (2005) study on British academic SIEs shows the relevance of the individuals' motivations with regards to moving to and returning from an international work experience. Their study finds that both agency and structure themes influence the SIE's motivation. Second, 


\section{CDI}

18,1 self-initiated expatriation discusses the international experience of individuals in managerial positions (Biemann and Andresen, 2010). These are described as being endowed with various types of capitals that include education, professional experiences and networks (Cao et al., 2012). They enjoy great opportunities and choices when they undertake international mobility, and gain a successful career experience as a result. On the contrary, whenever the discussion uses the term "migrant", the emphasis is on work/employment (rather than careers) that often occur under harsh conditions of under-employment and even unemployment. Here again, as opposed to migrants, the literature suggests that career choices and outcomes for SIEs are boundaryless. In such settings, national and international contexts seem of little importance; it is the ability of SIEs to cross boundaries that is emphasized. Rather globalization is frequently presented as the new way to understand careers in our contemporary world. Surprisingly, unlike SIEs, most discussions on migration are loaded with structural (e.g. institutional and organizational) barriers and the internationally mobile migrant seems only to encounter boundaries. Such boundaries include limited possibilities to cross-geographies; and, even when spatial boundaries are crossed, further boundaries exist in terms of obtaining work permits and finding jobs. Table I provides some key sources to support our discussion.

In contrast to the case of SIE, management studies use the term migrant when discussing the work experiences of unskilled individuals, having less educated backgrounds, and originating from less-developed countries. This narrow focus in the management-related literature might be linked to the fact that other journals such as Migration Letters, International Migration, International Migration Review, and The Journal of Ethnic and Migration Studies have targeted their research with more in-depth analysis of the topic of migration. Nevertheless, there are few authors such as Berry (2009) and Berry and Bell (2011) who break this line of distinction between SIE and migrants and call, in their work for more diverse and open management research in this regard.

Discussions of migration in management studies have two key methodological features that influence the themes that are discussed. On the one hand, quantitative studies focus on macro-contextual issues such as economic benefits of migration for the labor markets, statistics regarding educational and professional attainments, unemployment, disability, self-employment, brain drain/gain among other topics. On the other hand, qualitative studies focus on the professional experiences of migrants in the context of the management of ethnic diversity. For example, drawing on qualitative in-depth interviews with ethnic minority and majority individuals, Kamenou (2008) shows that ethnic minority women often had to deal with additional cultural, community or religious demands in finding work-life balance. In another on the experiences of Bangladeshi, Caribbean and Pakistani women working in the public sector in the UK, Healy et al. (2011) examine how inequalities are produced and reproduced in the context of workplace. In these same studies, context and history are presented as essential to understand the experiences of migrants. For instance, in a qualitative study on Turkish-Cypriots in the UK, Inal and Özkan (2011) argue that the life and career trajectory of migrants from ethnic minorities is marked by their history of ethnicity and migration. International experience emerges as characterized by dual processes of break with tradition and later return to tradition. During this process, migrants' identities are tested and usually reaffirmed, such as in the case of Turkish Cypriots who rediscovered their Turkish Cypriotness (Table II). 


\section{Characteristics}

Country of origin

Gender

Education and skills

Job positions

Organizations

Period of international mobility

Destination countries

Description of context
Profiles of migrants

Ethnic minorities from various Asian (e.g. India) and African (e.g. Zimbabwe, Nigeria) countries, Arab countries and Middle East (e.g. Lebanon, Morocco, Turkey), Mexico, Eastern Europe (e.g. Moldavia and Romania), Madagascar (Ramboarison-Lalao et al., 2012)

Men represented in the samples/participants more than women

Unskilled and less educated

Those studies which do focus on qualified migrants do so in the context of either unemployment or under-employment

Workers, self-employed individuals

Medium and small size companies, self-employment

Longer terms (several years) and permanent

Western Europe, USA, Australia, New Zealand, Canada

Focus on challenges, lack of work rights, discrimination, macrocontext issues of labor mobility

Focus on constraints imposed by structures (government agencies, labor markets, business sectors) and less on agency of migrants and their ability to act

Less focus on career experiences and greater emphasis on unemployment issues

\section{SIE and migration in the literature}

83

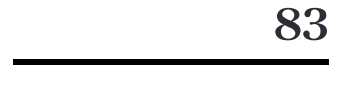

Table II.

Who migrants are in the management literature?

What do we know about SIEs compared to migrants from management studies?

SIE research draws, in a balanced way, on both qualitative and quantitative methods in order to explore a large variety of topics. These topics include: reasons for undertaking an expatriation, career capital, career strategies of SIEs, career outcomes and successes, repatriation, among other key issues that are indicated in Table III. Nevertheless, very few studies employed mixed methods building on multiple data sources. We present a brief sketch of some important themes in this literature.

The reasons behind self-initiated expatriation are related to financial, personal, family, search for adventure and career advancement issues (Inkson and Myers, 2003; Carr et al., 2005). The agentic ability to improve one's lifestyle and quality of living is considered an SIE motivation, rather than a forced move for economic reasons (Crowley-Henry, 2010). Learning about different cultural settings and establishing new international contacts are indicated to be important motives (Myers and Pringle, 2005). Besides, the desire for new life journeys and discovering different ways of living are among the reported reasons for SIE (Richardson and McKenna, 2003). It is frequent that researchers compare SIE and expatriates that are sent by their companies (Suutari and Brewster, 2000; Cerdin and Pargneux, 2010; Doherty et al., 2011). Both SIEs and corporate expatriates are found to engage in pursuit of personal and professional developments, with their individual agency underlined.

The literature focuses on highly educated and skilled individuals. SIEs are therefore presented as possessing career capital. The concept of career capital offers a connection between three forms of knowledge that are assumed to be essential for the career development of SIEs. These are: knowing-why, knowing-how, and knowing-whom 


\section{CDI \\ 18,1}

84

What does management research tell us about SIEs?
Themes on SIE

1 International career behaviors (Agullo and Egawa, 2009)

2 Career strategies in self-initiating expatriation (Al Ariss and Syed, 2011)

3 Adjustment of self-initiated expatriates/repatriates to their countries (Begley et al., 2008)

4 How SEs and AEs differ with respect to their reasons for working internationally (Doherty et al., 2011) and regarding their career capitals (Jokinen et al., 2008), career aspirations and orientations, and in what way their individual career strategies differ (Biemann and Andresen, 2010)

5 The relationship of job satisfaction and turnover intentions: cross-cultural training, protege experience, peer support, and the cultural clusters of the home and host countries (Bozionelos, 2009)

6 Boundaryless career experiences of SIEs and the careers of their spouses (Eby, 2001)

7 Opportunities HRM can play in supporting the adjustment of self-initiated expatriates to the new organization and culture (Howe-Walsh and Schyns, 2010)

8 Demographic profiles (e.g. marital status, gender) of self-initiated expatriates (Selmer and Lauring, 2011a; Selmer and Lauring, 2011b)

9 Reasons to expatriate/repatriate explained by push/pull factors (Thorn, 2009; Tharenou and Caulfield, 2010); career outcomes for SIE (Selmer and Lauring, 2011a, b)

10 Careers of SIE women: what causes women to self-initiate expatriation? Women's proactivity to redress the disadvantage they face in managerial career advancement. SIE women's repatriation and career outcomes (Tharenou, 2010)

Gender differences in terms of reasons to expatriate (Thorn, 2009)

11 Career patterns of SIEs from specific groups such as academics (Richardson, 2009), nurses (Bozionelos, 2009) and other professionals (Thorn, 2009)

competencies (DeFillippi and Arthur, 1996). Knowing-why is related to personal motivations to pursue a selected career path. For example, in the case of SIEs, this is linked to what motivates their decisions on whether and where to go (Carr et al., 2005). The knowing-how competencies are often presented in a similar manner to classical human capital meanings. These consist of individuals' knowledge, for example, education, skills, and work experience of SIEs. Finally, knowing-whom competencies are linked to relational and professional networks such as meeting people helpful to career advancement. Networks provide opportunities for using and developing human capital.

Linked to the previous discussion, the literature suggests that SIEs accumulate and use career capital to accomplish career success. In the context of SIE, subjective success is mainly discussed. Subjective success for SIEs is connected to their feelings of job satisfaction, and work-life balance such as through greater involvement with family life. It is common that SIEs prefer work-life balance more than power, prestige, money, and vertical advancement in their careers (Inkson, 2008). This acknowledgement of potentially reduced power and access up the hierarchy is emphasized for female SIEs (Crowley-Henry and Weir, 2007; Tharenou, 2010).

Management research on migration draws essentially on quantitative methods. Unlike SIEs, migrants are portrayed as being discriminated against in their 
professional experiences, they are unemployed or underemployed, do not enjoy full career choices, and emphasis is made on their demographics such as their level of education.

Research concludes that host countries' organizations and institutions benefit when migrants' human capital is properly used (Salaff et al., 2002). Studies recognize that the career experiences of skilled individuals traveling on their own initiative and working in host countries remain largely under-researched (Collings et al., 2007). For example, immigrant women are filling increasingly skilled jobs (Bach, 2007). Nevertheless, skilled immigration is an area where women's career experiences remains, up to a certain point, hidden.

The literature discusses downward career mobility for skilled migrants. This occurs when skilled migrants make a career step back by taking jobs that under-use their educational level and skills (Al Ariss and Özbilgin, 2010). Furthermore, studies are bourgeoning regarding the role of the state and organizations in regulating labor migration and shaping the experiences of migrants in the source and host countries. This is discussed mainly in journals on industrial relations. Bach (2007) argues that studies focus mainly on the general behavior of migrants (e.g. integration, brain drain, brain again) while neglecting the role of the state and organizations in the migration process (Table IV).

Having reviewed the management literature, so far we have addressed two key issues: first, how SIEs are portrayed compared to migrants; and second, the state-of-the art knowledge about SIEs compared to migrants. Building on our findings, the next section discusses what can be learned from the management literature on both migration and SIE that offers research opportunities to studies on SIEs.

\section{A research map for future studies on self-initiated expatriation}

Our review demonstrates four important issues that are lacking in the existing research on SIE. In this section, we present these knowledge gaps and propose a map for future direction on SIE research. These gaps are:

(1) Focus is on the most privileged individuals in terms of their ethnicity, education, and professional positioning. Our research map calls for diversity-informed research on SIE.

(2) SIE research lacks contextualization. For example, there are several key topics that need further exploration, including understanding the national contexts of the home and host countries of self-initiated expatriates, establishing a deeper comprehension of the relation between self-initiated expatriation and migration policies in the host country, taking into account the history of migration and migration groups in the host countries and its relation with self-initiated expatriation, and exploring transnational links of SIEs with their home countries. We suggest that SIE studies need to be more context-specific and emphasize the multilevel nature of expatriation.

(3) More broadly, the SIE scholarship often employs the term "SIE" and "migrant" without fully questioning their meanings and the implication of their use. This leads to enhancing an image of the expatriate who is full of agency, able to make free career choices, while enforcing an image of migrants as "second-class expatriates" who are subject to exclusion and structural barriers. We call for

\section{migration in the}

literature

85




\section{CDI \\ 18,1}

86

Table IV.

What does management research tell us about migrants?
Themes on migrants

1 Strategies to relocate from home to host countries and strategies to advance their careers in the host countries (Al Ariss and Syed, 2011)

2 How ethnic linkages/networks affect the location choice of migrants (Bauer et al., 2009)

3 The international employment experiences of female migrants and the challenges they face in a foreign country (Bodolica and Spraggon, 2008)

4 Job non-satisfaction of academics in their home countries and their international migration to other countries (Chimanikire et al., 2007)

5 Migrants' entrepreneurship (Harney, 2006); How the probability of self-employment for migrants changes with time / comparisons between the different migrant ethnic groups in term of self-employment (Clark and Drinkwater, 2009)

6 Migrant workers' rights (Deacon et al., 2011)

7 Integration of migrants within the host countries' workforce and the future that migrant workers see for themselves discussed from a human resource perspective (Devine et al., 2007)

8 Research on how public labor migration policies support refugees from their arrival into their employment in host countries (Diedrich and Styhre, 2008) Link between national diversity policies and migration (Healy and Oikelome, 2007)

9 Geographical mobility among unemployment benefit recipients, including migrants (e.g. in Australia) (Dockery, 2000)

10 The link between migration on the gendering of service work (Dyer et al., 2010)

11 Brain drain issues (Gaiduk et al., 2009)

12 The link between migration and professional sports (Madichie, 2009)

13 Intermarriage, language, and economic assimilation of migrants (Meng and Meurs, 2009)

14 Immigrants with disabilities: analysis of their social and demographic features, such as regional distribution by country of origin, level of education or degree of integration into working life, exclusion patterns (Meseguer-Santamaria et al., 2010)

15 Barriers in finding jobs for skilled professional migrants in countries such as Canada (Salaff et al., 2002)

Language deficit affecting the labor market experiences of migrants (e.g. migrant women in Australia) (Syed and Murray, 2009)

16 Identity of migrants in the context of host countries' organizations (Siebers, 2009)

How different aspects of migrant pre-migration characteristics (human capital and motivation to migrate) and post-migration behavior (social integration and career self-management) predict migrants' post-migration career success (Tharmaseelan et al., 2010)

more reflexive approaches on SIE that question and critique the central assumptions of this area.

(4) Few SIE studies employ both qualitative and quantitative methods and use multiple data sources. Our map builds on the utility of triangulated approaches that enhance our knowledge of this topic. Figure 1 highlights the four dimensions of our research map. 


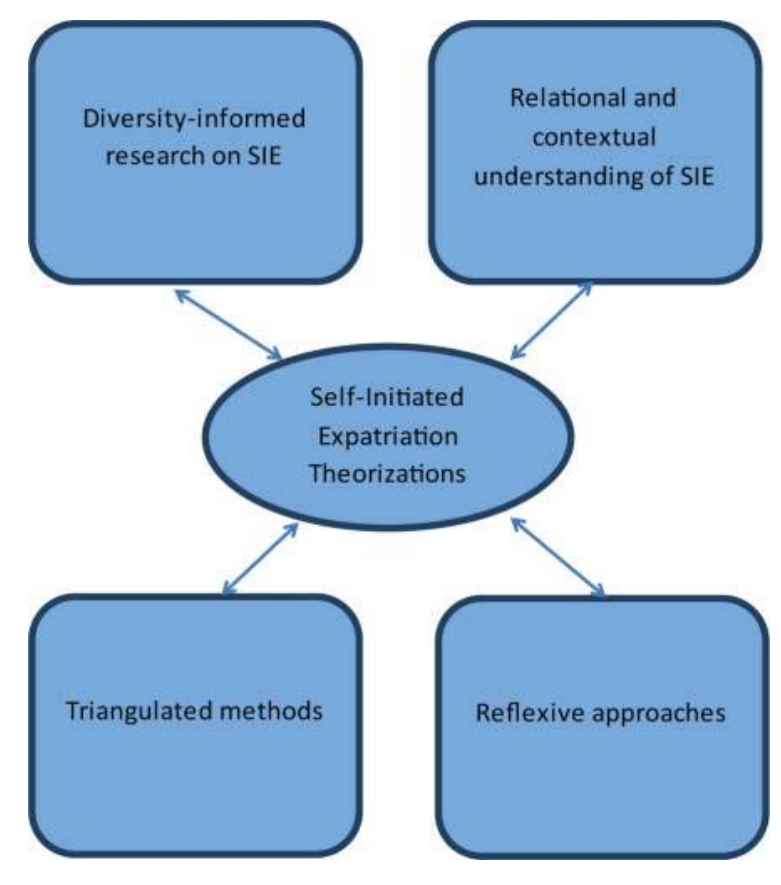

\section{SIE and migration in the literature}

Figure 1.

Research map for future studies on self-initiated expatriation

\section{Research on SIE informed by diversity in the workplace}

$\mathrm{SIE}$ is an area where career experiences remain largely confined to privileged individuals undertaking expatriation. This can be explained by the fact that researchers in this area come from these same privileged groups. Thus, it is important to include the less privileged, in terms of their skills, sex, ethnicity, and physical disabilities, that also constitute an important facet of international mobility. While recent literature suggests that females and males self-initiate their expatriation in about equal numbers (e.g. Tharenou, 2010, p. 75); nevertheless, the focus is on White women SIEs from developed countries, with less attention given to the intersection of ethnicity and gender relations for ethnic minority women. Gendered and ethnic relations are increasingly found in people's every day work and life activities and thus influence career choices and outcomes of female ethnic minority SIEs (Bourne and Ozbilgin, 2008). The influence of gender, for instance, leads to unequal representation of women in science, technology, and engineering professions across the world (Bourne and Özbilgin, 2008). We argue that gender and diversity need more attention in SIE research. In addressing "second class SIEs" within the current confines of the SIE category (such as female or minority-group SIEs), which is in itself heterogeneous, we can build on linkages and commonalities between migrants and SIEs, and thereby deepen our knowledge of international mobility.

\section{Relational and contextual understanding of SIE}

There are increasing calls for linking the individual, organizational, and macro-contextual levels in SIE studies rather than opposing them or focusing on just one level. It is important to consider the role of both structures (such as 


\section{CDI \\ 18,1}

governmental institutions, NGOs, and organizations) and individuals in shaping the work and life choices and outcomes of SIEs. For example, at the macro-contextual level, it would be interesting to investigate further the "unspoken" motives of institutions in managing the different forms of labor migration. It would be also interesting to investigate the extent to which institutions provide support for organizations in terms of employment of self-initiated expatriates; the pull factors. At the organizational level, Inkson (2008) suggests that the relation linking employees to their organizations should be understood in terms of partnership leading to mutual benefits. This applies to future research on SIE that could balance between the individual choices and organizational needs in terms of human resource management. At the individual level, the subjective experiences of SIEs allow to understand their career trajectories, throughout time, in order to gain a better understanding of their international professional experiences.

Al Ariss et al. (2012) argue that by recognizing the contextual nature of careers, scholars can gain a more nuanced understanding of international careers in their relevant geographical, historical, institutional and organizational settings. The same authors propose a multilevel approach (Table V) to studying careers of migrants that we also call to adopt in research on SIE. If their model is applied to SIE, the micro-individual level would refer to the subjective work-life experiences of SIEs. The meso-organizational level would take into account how organizations shape the careers of SIE. The macro-contextual level would consider the role of institutional interventions, as well as social, political, and economic factors that can limit or enable the careers of SIEs.

\section{Reflexive approaches in studying SIE}

Research design in management publications, including on self-initiated expatriation, is often "represented as a fait accompli" (Johnson et al., 1999, p. 1234) that is unquestioned with regards to the matters that influenced it. In line with researchers who call for reflexive research (Johnson et al., 1999; Swan, 2008), we call for more reflexivity in future studies on SIEs. The lack of reflexivity in management studies

\begin{tabular}{ll}
\hline Broad levels & Specific themes \\
\hline Macro-context & $\begin{array}{l}\text { Regional and national legislation/policies/guidelines on the employment } \\
\text { and work of SIEs, country(ies) of origin/destination(s), discriminatory and } \\
\text { anti-discriminatory policies, diversity policies, unemployment settings, } \\
\text { formal policies of recognition of education and skills of SIEs }\end{array}$ \\
Organizational level & $\begin{array}{l}\text { Human resource management strategies for SIEs, discrimination practices } \\
\text { against SIEs, diversity strategies/practices for accommodating SIEs, }\end{array}$ \\
& $\begin{array}{l}\text { underemployment of SIEs in organizations, human resource development } \\
\text { strategies }\end{array}$ \\
Individual level & $\begin{array}{l}\text { Agency of SIE from minority groups, work-life experiences of SIEs from } \\
\text { minority groups, strategies of leaving a country for another one, strategies }\end{array}$ \\
& to overcome structural barriers in the destination country, experiences of \\
SIEs in terms of their ethnicity/religion/sex/age/physical abilities among \\
other characteristics, link between experiences in the home/destination \\
countries
\end{tabular}

Table V.

Key levels and future research themes on SIEs

Source: Adapted from Al Ariss et al. (2012) 
might be linked to the fact that publishing traditions, because of positivist assumptions, are against discussing research ambiguities. Another reason is that researchers might find it difficult to present research ambiguities in a reasonable manner (Johnson et al., 1999). Because "the difficulties, practicalities, and methods of doing" (Mauthner and Doucet, 2003, p. 143) reflexivity are absent in published work on SIE, researchers appear to have neutral-value on choices of research design, analysis, and findings and terminology.

Reflexivity allows overcoming apparent neutrality in social sciences by questioning the way in which the process of research is carried out (Hardy et al., 2001). This takes place when researchers explain that their research on SIE "comes from a particular standpoint" (Swan, 2008, p. 395). Reflexivity also occurs by recognizing that individuals, including the researchers, impose a vision of reality that corresponds to their point-of-view (Bourdieu, 2001, p. 172). Al Ariss (2012) suggests that there are two key conditions for reflexivity: one is related to the researcher and the other to research participants. In the context of SIE, first, reflexivity requires that SIE researchers demonstrate their awareness throughout the research process of their own personal experiences and assumptions, which influence their understanding of the phenomena under investigation (Easterby-Smith, 2008). For example, researchers could recognize that they have implicit/explicit beliefs about their choice of the group of SIE that is researched, the importance of the research questions, their understanding of the data, among other issues. In this paper, for example, our position comes from our particular interest and understanding of diversity and equality in management studies, including how SIEs and migrants are considered in the literature. This position has shaped our research and review here, in how we question assumptions and propose a more critical and fundamental reflection on, and unpacking of, why migrants and SIEs are actually more similar than different.

Second, reflexivity in research on SIE also supposes recognizing the subjectivist nature of the experiences research participants rather than taking these as a complete objective truth. This requires questioning participants' presuppositions, and how these can influence the research design, data collection and analysis, as well as research conclusions. For instance, one can be reflective when doing qualitative interviews with policy-makers on the topic of labor migration policies. In this particular case, the importance of questioning institutional discourses has been described as follows:

The trick of dealing with the hierarchy of credibility is simple enough: doubt everything anyone in power tells you. Institutions always put their best foot forward in public. The people who run them, being responsible for their activities and reputations, always lie a little bit, smoothing over rough spots, hiding troubles, denying the existence of problems. What they say may be true, but social organization gives them reasons to lie. A well-socialized participant in society may believe them, but a well-socialized social scientist will suspect the worst and look for it (Becker, 1998, p. 91).

In sum, being reflexive in SIE research means to recognize that full objectivity remains unattainable as hidden motives and values, for both the researcher and the research participants, will always be present to influence the research process (Al Ariss, 2012). Documenting such issues, albeit in concise explanations in publications on SIE, makes it possible to report the conditions under which research is undertaken and therefore enhance the quality of future SIE studies.

\section{SIE and migration in the literature}




\section{CDI \\ 18,1}

\section{Triangulation in research methods}

Triangulation in SIE research consists of using more than one method and source of data in the study of international mobility. Examining information collected by different methods leads to reducing the impact of potential single-method biases by improving accuracy (McEvoy and Richards, 2006) and thus increasing researchers' understanding of reality (Creswell, 2003). In view of that, mixed quantitative and qualitative methods can be one way of diversifying data sources on SIE.

In this regard, while quantitative methods are useful in confirming theory that leads to general conclusions (Howard and Borland, 2001), and in giving indications such as what percentage of individuals undertaking expatriation think or behave in a certain way, they do not allow the researcher to delve into the details of the experiences of individuals. Here, qualitative methods can highlight the qualities of processes that are not experimentally examined in terms of quantity (Denzin and Lincoln, 2005). Using qualitative in-depth interviews in research on SIE allows revealing detailed data about individuals' career experiences that lead, therefore, to building theory. In line with this, reporting field notes can also be of great help. While recording qualitative interviewees allows capturing elements such as tone and the discourse of participants, brief notes can be taken concerning observational issues that could not be obtained from the interview process, such as participants' work environments, outside interactions, and facial expressions. This allows situating the accounts of the research participants and helps thus to provide better analysis and explanation. In addition, document analysis of labor migration policies can be helpful to understand the career choices available for SIEs.

\section{Conclusions}

While there is an increasing interest in understanding SIE, a comprehensive framework for theorizing and researching this area is lacking in management studies. This paper addresses this gap in that it presents a critical review of management literature to date on SIE and migration. From a systematic review of the existing management literature in this area, it pushes the boundaries of the research on SIE by synthetizing its key debates, comparing it to migration, and proposing a more relational and inclusive model for future studies. Rather than postulating a narrow focus on SIE, the paper argues that the theoretical weaknesses concerning this topic could be better addressed through a research agenda that is more inclusive in nature.

Specifically, the paper contributes to career and management studies on SIE by setting out a research framework that has four important dimensions. These dimensions are:

(1) diversity-informed;

(2) context-specific;

(3) reflexive; and

(4) methodologically triangulation-sensitive.

We suggest that, in order to better understand the SIE group, including their experiences, motivations, and implications for organizations, a more comprehensive research framework is required. Therefore, our review and framework engages with a more diverse analysis of SIE from different theorizations and from different research approaches. 
A deeper understanding of SIE for management scholars, would ultimately, in turn, lead to better inclusive practices across the organizational and national spectrums for accommodating individuals on international mobility. The benefits of these meso-organizational and macro-national contributions would also enhance the micro-individual experience of SIEs.

\section{References}

Agullo, B. and Egawa, M. (2009), "International careers of Indian workers in Tokyo: examination and future directions", Career Development International, Vol. 14 Nos 2-3, pp. $148-68$.

Al Ariss, A. (2010), "Modes of engagement: migration, self-initiated expatriation, and career development", Career Development International, Vol. 15 No. 4, pp. 338-58.

Al Ariss, A. (2012), "Migration or self-initiated expatriation? Questioning terminology in international management studies", in Andresen, M., Al Ariss, A., Walther, M. and Wolff, K. (Eds), Self-Initiated Expatriation: Mastering the Dynamics, Routledge, New York, NY.

Al Ariss, A. and Syed, J. (2011), "Capital mobilization of skilled migrants: a relational perspective”, British Journal of Management, Vol. 22 No. 2, pp. 286-304.

Al Ariss, A., Koall, I., Özbilgin, M. and Suutari, V. (2012), "Careers of skilled migrants: towards a theoretical and methodological expansion", Journal of Management Development, Vol. 31 No. 2.

Bach, S. (2007), "Going global? The regulation of nurse migration in the UK", British Journal of Industrial Relations, Vol. 45 No. 2, pp. 383-403.

Bauer, T., Epstein, G.S. and Gang, I.N. (2009), "Measuring ethnic linkages among migrants", International Journal of Manpower, Vol. 30 Nos 1-2, pp. 56-69.

Becker, H.S. (1998), Tricks of the Trade: How to Think About your Research While You're Doing It, The University of Chicago Press, Chicago, IL.

Begley, A., Collings, D.G. and Scullion, H. (2008), "The cross-cultural adjustment experiences of self-initiated repatriates to the Republic of Ireland labour market", Employee Relations, Vol. 30 No. 3, pp. 264-82.

Bergh, R.v.d. and Plessis, Y.D. (2012), "Highly skilled migrant women: a career development framework", Journal of Management Development, Vol. 31 No. 2.

Berry, D. (2009), "Expatriates, migrants, gender, race, and class", Academy of Management Proceedings in Chicago, IL, USA, August, 2009, Business Source Elite, Ipswich, pp. 1-6.

Berry, D.P. and Bell, M.P. (2011), “Expatriates': gender, race and class distinctions in international management", Gender, Work \& Organization, Vol. 19 No. 1, pp. 10-28.

Biemann, T. and Andresen, M. (2010), "Self-initiated foreign expatriates versus assigned expatriates: two distinct types of international careers?", Journal of Managerial Psychology, Vol. 25 Nos 3-4, pp. 430-48.

Bodolica, V. and Spraggon, M. (2008), "Work experiences of Moldovan women in Italy: bearing the double identity strangeness", Equality, Diversity and Inclusion: An International Journal, Vol. 27 No. 6, pp. 537-58.

Bourdieu, P. (2001), Masculine Domination, Stanford University Press, Stanford, CA.

Bourne, D. and Ozbilgin, M.F. (2008), "Strategies for combating gendered perceptions of careers", Career Development International, Vol. 13 No. 4, pp. 320-32. 
CDI

18,1

92
Bozionelos, N. (2009), "Expatriation outside the boundaries of the multinational corporation: a study with expatriate nurses in Saudi Arabia”, Human Resource Management, Vol. 48 No. 1, pp. 111-34.

Cao, L., Hirschi, A. and Deller, J. (2012), "Self-initiated expatriates and their career success", Journal of Management Development, Vol. 31 No. 2.

Carr, S.C., Inkson, K. and Thorn, K. (2005), "From global careers to talent flow: reinterpreting 'brain drain'”, Journal of World Business, Vol. 40 No. 4, pp. 386-98.

Cerdin, J.-L. and Pargneux, M.L. (2010), "Career anchors: a comparison between organization-assigned and self-initiated expatriates", Thunderbird International Business Review, Vol. 52 No. 4, pp. 287-99.

Chimanikire, P., Mutandwa, E., Gadzirayi, C.T., Muzondo, N. and Mutandwa, B. (2007), "Factors affecting job satisfaction among academic professionals in tertiary institutions in Zimbabwe", African Journal of Business Management, Vol. 1 No. 6, pp. 166-75.

Clark, K. and Drinkwater, S. (2009), "Immigrant self-employment adjustment: ethnic groups in the UK”, International Journal of Manpower, Vol. 30 Nos 1-2, pp. 163-75.

Collings, D.G., Scullion, H. and Morley, M.J. (2007), "Changing patterns of global staffing in the multinational enterprise: challenges to the conventional expatriate assignment and emerging alternatives", Journal of World Business, Vol. 42 No. 2, pp. 198-213.

Creswell, J.W. (2003), Research Design- Qualitative, Quantitative, and Mixed Methods Approaches, 2nd ed., Sage Publications, Thousand Oaks, CA.

Crowley-Henry, M. (2010), "21st century international careers: from economic to lifestyle migration”, in Hogan, J., Donnelly, P. and O’Rourke, B. (Eds), Irish Business \& Society. Governing, Participating \& Transforming in the 21st Century, Macmillan, Dublin.

Crowley-Henry, M. (2012), "Re-conceptualizing the career development of self initiated expatriates: rivers not ladders", Journal of Management Development, Vol. 31 No. 2.

Crowley-Henry, M. and Weir, D. (2007), "The international protean career: four women's narratives”, Journal of Organizational Change Management, Vol. 20 No. 2, pp. 245-58.

Deacon, B., De Lombaerde, P., Macovei, M.C. and Schroder, S. (2011), "Globalisation and the emerging regional governance of labour rights", International Journal of Manpower, Vol. 32 No. 3, pp. 334-65.

DeFillippi, R.J. and Arthur, M. (1996), "Boundaryless contexts and careers: a competency-based perspective", in Arthur, M.B. and Rousseau, D. (Eds), The Boundaryless Career: A New Employment Principle for a New Organizational Era, Oxford University Press, Oxford.

Denzin, N.K. and Lincoln, Y.S. (2005), "Introduction: the discipline and practice of qualitative research", in Denzin, N.K. and Lincoln, Y.S. (Eds), The Sage Handbook of Qualitative Research, Sage, Thousands Oaks, CA, pp. 1-36.

Devine, F., Baum, T., Hearns, N. and Devine, A. (2007), "Cultural diversity in hospitality work: the Northern Ireland experience", International Journal of Human Resource Management, Vol. 18 No. 2, pp. 333-49.

Dickmann, M. and Baruch, Y. (2011), Global Careers, Routledge, New York, NY.

Diedrich, A. and Styhre, A. (2008), "Making the refugee multiple: the effects of classification work", Scandinavian Journal of Management, Vol. 24 No. 4, pp. 330-42.

Dockery, A.M. (2000), "Regional unemployment rate differentials and mobility of the unemployed: an analysis of the FaCS longitudinal data set", International Journal of Manpower, Vol. 21 No. 5, pp. 400-23. 
Doherty, N., Dickmann, M. and Mills, T. (2011), "Exploring the motives of company-backed and self-initiated expatriates", International Journal of Human Resource Management, Vol. 22 No. 3, pp. 595-611.

Dyer, S., McDowell, L. and Batnitzky, A. (2010), "The impact of migration on the gendering of service work: the case of a West London hotel", Gender Work and Organization, Vol. 17 No. 6, pp. 635-57.

Easterby-Smith, M., Golden-Biddle, K. and Locke, K. (2008), "Working with pluralism: determining quality in qualitative research", Organizational Research Methods, Vol. 11 No. 3, pp. 419-29.

Eby, L.T. (2001), "The boundaryless career experiences of mobile spouses in dual-earner marriages", Group \& Organization Management, Vol. 26 No. 3, pp. 343-68.

Eures (2012), Rules on the Free Movement of Workers, available at: http://ec.europa.eu/eures/ main.jsp?countryId $1 \frac{1}{4}$ AT\&acro $1 / 4$ living\&lang $1 / 4$ en\&parentId $1 / 40$

Eurofound (2012), Free Movement of Workers, available at: www.eurofound.europa.eu/areas/ industrialrelations/dictionary/dictionary6.htm (accessed 11 December 2011).

European Commission Education \& Training (2012), The ERASMUS Programme - Studying in Europe and More, available at: http://ec.europa.eu/education/lifelong-learningprogramme/doc80_en.htm (accessed 8 June 2010).

European Commission Research (2012), Marie Curie Actions Human Resources and Mobility Activity, available at http://ec.europa.eu/research/fp6/mariecurie-actions/action/fellow_en. html (accessed 20 January 2006).

Gaiduk, R., Gaiduk, J. and Fields, D. (2009), "Limiting the brain drain: determinants of employee organizational attachment in Lithuania”, Baltic Journal of Management, Vol. 4 No. 2, pp. 149-68.

Hardy, C., Phillips, N. and Clegg, S.R. (2001), "Reflexivity in organization and management theory: a study of the production of the research 'subject", Human Relations, Vol. 54 No. 5, pp. 531-60.

Healy, G. and Oikelome, F. (2007), "A global link between national diversity policies? The case of the migration of Nigerian physicians to the UK and USA", International Journal of Human Resource Management, Vol. 18 No. 11, pp. 1917-33.

Healy, G., Bradley, H. and Forson, C. (2011), "Intersectional sensibilities in analysing inequality regimes in public sector organizations", Gender, Work and Organization, Vol. 18 No. 5, pp. 467-87.

Howard, R.D. and Borland, K.W. (2001), Balancing Qualitative and Quantitative Information for Effective Decision Support, Jossey-Bass, San Francisco, CA.

Howe-Walsh, L. and Schyns, B. (2010), "Self-initiated expatriation: implications for HRM", International Journal of Human Resource Management, Vol. 21 No. 2, pp. 260-73.

Inal, G. and Özkan, M.K. (2011), "Multi-layered analysis of Turkish Cypriot female solicitors' career trajectory in North London", Equality Diversity and Inclusion: An International Journal, Vol. 30 No. 6, pp. 510-23.

Inkson, K. (2008), “Are humans resources?”, Career Development International, Vol. 13 No. 3, pp. 270-9.

Inkson, K. and Myers, B.A. (2003), "The big OE: self-directed travel and career development", Career Development International, Vol. 8 No. 4, pp. 170-81.

Inkson, K., Arthur, M.B., Pringle, J. and Barry, S. (1997), "Expatriate assignment versus overseas experience: contrasting models of international human resource development", Journal of World Business, Vol. 32 No. 4, pp. 351-68. 


\section{CDI}

18,1

Johnson, P., Duberley, J., Close, P. and Cassell, C. (1999), "Negotiating field roles in manufacturing management research: the need for reflexivity", International Journal of Operations \& Production Management, Vol. 19 No. 12, pp. 1234-53.

Jokinen, T., Brewster, C. and Suutari, V. (2008), "Career capital during international work experiences: contrasting self-initiated expatriate experiences and assigned expatriation", International Journal of Human Resource Management, Vol. 19 No. 6, pp. 979-98.

Kamenou, N. (2008), "Reconsidering work-life balance debates: challenging limited understandings of the 'life' component in the context of ethnic minority women's experiences", British Journal of Management, Vol. 19, pp. S99-S109.

McEvoy, P. and Richards, D. (2006), "A critical realist rationale for using a combination of quantitative and qualitative methods", Journal of Research in Nursing, Vol. 11 No. 1, pp. 66-78.

Madichie, N. (2009), "Management implications of foreign players in the English Premiership League football", Management Decision, Vol. 47 No. 1, pp. 24-50.

Mauthner, N.S. and Doucet, A. (2003), "Reflexive accounts and accounts of reflexivity in qualitative data analysis", Sociology, Vol. 37 No. 3, pp. 413-31.

Meng, X. and Meurs, D. (2009), "Intermarriage, language, and economic assimilation process: a case study of France”, International Journal of Manpower, Vol. 30 Nos 1-2, pp. 127-44.

Meseguer-Santamaria, M.L., Mondejar-Jimenez, J. and Vargas-Vargas, M. (2010), "Immigrants with disabilities in Spain”, African Journal of Business Management, Vol. 4 No. 18, pp. 4021-8.

Myers, B. and Pringle, J. (2005), "Self-initiated foreign experience as accelerated development: influences of gender", Journal of World Business, Vol. 40 No. 4, pp. 421-31.

Ramboarison-Lalao, L., Al Ariss, A. and Barth, I. (2012), "Careers of skilled migrants: understanding the experiences of Malagasy physicians in France", Journal of Management Development, Vol. 31 No. 2.

Richardson, J. (2006), “Self-directed expatriation: family matters”, Personnel Review, Vol. 35 No. 4, pp. $469-86$.

Richardson, J. (2009), "Geographic flexibility in academia: a cautionary note", British Journal of Management, Vol. 20, S1, pp. S160-70.

Richardson, J. and McKenna, S. (2003), "International experience and academic careers: what do academics have to say?", Personnel Review, Vol. 32 No. 6, pp. 774-95.

Richardson, J. and Mallon, M. (2005), "Career interrupted? The case of the self-directed expatriate”, Journal of World Business, Vol. 40, pp. 409-20.

Salaff, J., Greve, A. and Ping, L.X.L. (2002), "Paths into the economy: structural barriers and the job hunt for skilled PRC migrants in Canada", International Journal of Human Resource Management, Vol. 13 No. 3, pp. 450-64.

Selmer, J. and Lauring, J. (2011a), "Marital status and work outcomes of self-initiated expatriates: is there a moderating effect of gender?", Cross Cultural Management: An International Journal, Vol. 18 No. 2, pp. 198-213.

Selmer, J. and Lauring, J. (2011b), "Self-initiated academic expatriates: inherent demographics and reasons to expatriate", European Management Review, Vol. 7 No. 3, pp. 169-79.

Siebers, H. (2009), "Struggles for recognition: the politics of racioethnic identity among Dutch national tax administrators", Scandinavian Journal of Management, Vol. 25 No. 1, pp. 73-84.

Suutari, V. and Brewster, C. (2000), "Making their own way: international experience through self-initiated foreign assignments", Journal of World Business, Vol. 35 No. 4, pp. 417-36. 
Swan, E. (2008), "Let's not get too personal: critical reflection, reflexivity and the confessional turn", Journal of European Industrial Training, Vol. 32 No. 5, pp. 385-99.

Syed, J. and Murray, P. (2009), "Combating the English language deficit: the labour market experiences of migrant women in Australia", Human Resource Management Journal, Vol. 19 No. 4, pp. 413-32.

Tharenou, P. (2010), "Women's self-initiated expatriation as a career option and its ethical issues", Journal of Business Ethics, Vol. 95 No. 1, pp. 73-88.

Tharenou, P., and Caulfield, N. (2010), "Will I stay or will I go? Explaining repatriation by self-initiated expatriates", Academy of Management Journal, Vol. 53 No. 5, pp. 1009-28.

Tharmaseelan, N., Inkson, K. and Carr, S.C. (2010), "Migration and career success: testing a time-sequenced model", Career Development International, Vol. 15 Nos 2-3, pp. 218-38.

Thorn, K. (2009), "The relative importance of motives for international self-initiated mobility", Career Development International, Vol. 14 Nos 4-5, pp. 441-64.

Vance, C.M. (2005), "The personal quest for building global competence: a taxonomy of self-initiating career path strategies for gaining business experience abroad", Journal of World Business, Vol. 40 No. 4, pp. 374-85.

\section{Appendix}

Journal

Number of articles

International Journal of Manpower

International Journal of Human Resource Management

Organization Science

African Journal of Business Management

Management Science

Academy of Management Journal; Administrative Science Quarterly; Human

Relations

Career Development International; Harvard Business Review

Advances in Strategic Management A Research Annual; Baltic Journal of Management; California Management Review; Journal of Management Studies; Journal of Organizational Change Management; Scandinavian Journal of Management; Review of Industrial Organization; Strategic Management Journal Academy of Management Perspectives; Advances in Strategic Management; Asia Pacific Journal of Management; British Journal of Management; Cross Cultural Management: An International Journal; European Journal of Work and Organizational Psychology; Gender Work and Organization; Geography and Strategy; Group Organization Management; Human Resource Management; Human Resource Management Journal; Human Resource Management Review; Journal of International Management; Journal of Managerial Psychology; Journal of Occupational and Organizational Psychology; Management Decision; Personnel Review; Sloan Management Review; South African Journal of Economic and Management Sciences Other $^{\mathrm{a}}$

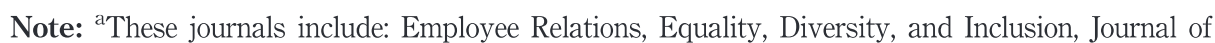
Management Development, Qualitative Research in Organizations and Management, Gender in Management, European Management Review, Journal of Business Ethics, and International Journal of Cross Cultural Management, Management International Review, and International Journal of Management

Table AI.

Frequency of articles by journal 
CDI

18,1

96
About the authors

Dr Akram Al Ariss, PhD, is Professor of Human Resource Management (HRM) at Toulouse Business School. He is a visiting professor at the London School of Economics in 2012 and is instructor at Pennsylvania State University (USA), where he lectures on international HRM and employment relations. He holds a $\mathrm{PhD}$ from Norwich Business School, University of East Anglia (UK). Akram is interested in researching and teaching IHRM. He has written book chapters, journal articles, and book reviews on HRM in journals such as the Academy of Management Learning and Education and British Journal of Management. He is the co-author (with Dessler) of the textbook Human Resource Management, Arab World Edition, published by Pearson. He serves on the Editorial Boards of Journal of World Business, British Journal of Management, and Equality, Diversity, and Inclusion. He is guest editor of special issues in journals like Journal of Managerial Psychology. Akram Al Ariss is the corresponding author and can be contacted at: Ariss_akram@hotmail.com

Dr Marian Crowley-Henry is a Lecturer in Human Resource Management and international management at the National University of Ireland Maynooth. She was awarded her $\mathrm{PhD}$ in Management from Lancaster University in 2009. Her current research interests are in the area of international careers, self-initiated expatriation, migration and identity. She has written book chapters, journal articles and conference papers in the international human resource management area, and is a reviewer for several management journals.

To purchase reprints of this article please e-mail: reprints@emeraldinsight.com Or visit our web site for further details: www.emeraldinsight.com/reprints 
T his article has been cited by:

1.Vivien Supangoo, W olfgang M ayrhofer. 2014. D eterm inantsofwork role transition outcom esofFilipinosin Singapore. JoumalofG bbalM dbility: T heH om eofExpatrateM anagem entR escardh 2:3, 317-342. [A bstract] [FullText] [PD F]

2.T oke Bjerregaard. 2014. Engaging institutions in gbbal careers: highly skilled self-initiated expatriates' jumeys through a N ordic welfare state. European M anagen ent Joumal32, 903-915. [C rossRef]

3.Susanne Bahn. 2014. M anaging the well-being of tem porary skilled $m$ igrants. T he International Joumal of $H$ um an ResourceM anagen ent 1-19. [C rossRef]

4.M arian C row ley-H enry, $G$ raham $H$ easlip. 2014. Short-term intemationalassignm ents. $M$ ilifary perspectives and im plications for intemationalhum an resourcem anagem ent. European $M$ anagen ent Joumal32, 752-760. [C rossef]

5.N kos Bozionebs, G iorgos Bozionelos, Konstantinos Kostopoulos, Chwen-H uey Shyong, Yehuda Baruch, W enxia Zhou. 2014. Intemational graduate students' perceptions and interest in international careers. T he InternationaljoumalofH um an ResourceM anagen ent1-24. [C rossRef]

6.Charles M . Vanœ, Yvonne M dN ulty. 2014. W hy and $H$ ow $W$ om en and M en Acquire G bbal Career Experienc. InternationalStudies of $M$ anagem ent and 0 rganization 44, 34-54. [C rossRef]

7. Jean-L uc Cerdin, Jan Sem er. 2014. W ho is a self-initiated expatriate? T owards œnœptual clarity of a com $m$ on notion. T he Internationaljoumal of $H$ um an R esourceM anagem ent 25, 1281-1301. [C rossRef]

8.Professor A kram A lA riss, Professor M ustafa Ö zbilgin, D r A hu T atli, Professor Kurt A pril and D r Elaine Swan, A kram AlA riss, M ustafä ठbilgin, A hu T atli, KurtA pril. 2014. Tackling W hitenessin organizations and $m$ anagem ent. JoumalofM anagerialPsydhobgy 29:4, 362-369. [A bstract] [FullT ext] [PD F]

9. Yusuf Silani, A kram AlA riss. 2014. Instihutional and corporate driers of gbbal talent m anagem ent: Evidenœ from the A rab G ulf region. JoumalofW orld Business 49:2, 215-224. [C rossRef]

10. Jean-L uc Cerdin, Chris Brewster. 2014. T alent m anagem ent and expatriation: Bridging two stream s of research and practice. JoumalofW orld Business 49:2, 245-252. [C rossRef]

11. Elaine Famdale, Avinash Pai, PaulSparrow, H ugh Saullion. 2014. Balancing individual and organizational goals in gbbal talentm anagem ent: A m utual-benefits perspective. JoumalofW orld Business 49 2, 2९4-214. [C rossRef]

12.A kram AlA riss, W ayne F. Cascio, Jaap Paauwe. 2014. Talent $m$ anagem ent: C urrent theories and future research directions. JoumalofW orld Business 49:2, 173-179. [C rossRef]

13.D avid G .C ollings. 2014. Integrating gbbalm obility and gbbaltalentm anagem ent: Explbring the challenges and strategic opportunities. JoumalofW orld Business 49:2, 253-261. [C rossRef]

14. L uciana T urchick H akak, A kram AlA riss. 2013. Vuherable work and intemationalm igrants: a relational hum an resource $m$ anagem ent perspective. T he InternationalJoumalofH um an Resource anagem ent 24:22, 4116-4131. [C rossRef]

15. Frithjof A rp, Kate H utchings, W endy A . Sm ith . 2013. Foreign executives in bcalorganisations. Joumal of G bbalM obility: T heH am eofExpatriateM anagem entR esarch 1:3, 312-335. [A bstract] [FullT ext] [PD F]

16. Sharon L .0 Sullivan . 2013.T heem powering potentialofsocialm ediafor key stakeholdersin the repatriation proœss. Joumal of bbalM dbility: T heH om e ofExpatriateM anagem ent Rearch 1:3, 264-286. [A bstract] [FullText] [PD F] 